Claudia Dahlerus, University of Colorado, Boulder

Heather Dash, Emory University

Leniece Davis, University of Chicago

Sarah J. Diel-Hunt, Southern Illinois

University

David M. Edelstein, University of Chicago

Christina Ewig, University of North

Carolina, Chapel Hill

Jason A. Frank, Johns Hopkins University

Gregory A. Fugate, University of Colorado, Boulder

Douglas Goodman, University of Utah

Elise Guiliano, University of Chicago

Jacob S. Hacker, Yale University

Michael Hammer, University of Michigan

Allen Hicken, University of California, San Diego

Donna Hoffman, University of Oklahoma

Valerie F. Hunt, University of Washington

Jacques E.C. Hymans, Harvard University

Mark T. Imperial, Indiana University,

Bloomington

Jennifer Jerit, University of Illinois, Urbana-Champaign

Cindy D. Kam, University of Michigan

Patricia Maria Keilbach, University of Oregon

Michael Kenney, University of Florida

Barbara M. King, Southern Illinois University

Sarah Kenyon Lischer, Massachusetts

Institute of Technology

Mary Malone, University of Pittsburgh

Vesna Marcina, University of California, Santa Barbara

Jody L. McMullen, University of Ari-

zona

Bonnie M. Meguid, Harvard University

Anne C. Miers, Rice University

Stephen Mockabee, Ohio State University

Kimberly Morgan, Princeton University Vincent Phillip Munoz, Claremont Graduate School

Thomas J. Nisley, University of Florida Jason L. Pierce, University of Texas, Austin

Lori Poloni-Staudinger, Indiana University, Bloomington

Robert W. Rauchhaus, University of

California, Berkeley

Daniel H. Roberts, Pennsylvania State University

Scott Robinson, Texas A\&M University

Thomas J. Rudolph, University of Minnesota

David Schecter, University of Florida

Ethan Scheiner, Duke University

Keesha Middlemass Scott, University of Georgia

Jennifer C. Seely, Washington University Evelyn Simien, Purdue University
Verity Smith, University of California, San Diego

Alexander Thompson, University of Chicago

Jaroslav Tir, University of Illinois, Ur-

bana-Campaign

Hans von Rautenfeld, University of

South Carolina

McGee Young, Syracuse University

\section{An International Annual Meeting}

As the APSA Annual Meeting becomes increasingly international in nature, the Association has increased its financial support to international scholars and students wishing to attend. Over the past five years, APSA has assisted hundreds of scholars through a combination of travel support, hotel accommodations, and complimentary meeting registrations.

This past year, the travel grant program received record high number of applications and APSA awarded $\$ 13,000$ to international scholars. The grantees represented 23 countries and came from 52 institutions worldwide.

For more information on APSA's travel grant program, please visit our web site (www.apsanet.org/about/ international/travel.cfm).

The names and affiliations of the 2000 winners follow.

Advanced International Graduate Student Travel Grant Program

Jungug Choi, University of Texas, Austin

Javier A. Couso, University of California, Berkeley

Frieda Fuchs, Harvard University

Thomas Gschwend, University at Stony

Brook, SUNY

Manjusta Gupte, Purdue University

Parakh N. Hoon, University of Florida Yusaku Horiuchi, Massachusetts Institute of Technology

Victoria Tin-bo Hui, Columbia University

Ji Hyang Jang, University of Texas, Austin

Sangbae Kim, Indiana University,

Bloomington

Katrin Kriz, Brandeis University

Bahar Leventoglu, University of Rochester

Dimitri Mitin, Purdue University

Gulenay Ozbek, New York University

Eleonora Pasotti, Columbia University
Grigore Pop-Eleches, University of California, Berkeley

Oxana Shevel, Harvard University

Maria Spirova, University. of Wisconsin, Milwaukee

Triadafilos Triadafilopoulos, New

School for Social Research

Erik Voeten, Princeton University

\section{Senior Scholar Travel Grant Program}

Ruth Abbey, University of Notre Dame Attila Agh, Budapest University of Economics

Karen Anderson, University of Twente Dan Anderson, Queen's University Daphna Canetti, University of Haifa Louise Chappell, University of Sydney Stephen Church, Victoria University Jonathan Davies, University of York Claes de Vreese, University of Amsterdam

Petra A. Dobner, University of Potsdam Stephen Fischer, Katholieke Unversiteit Leuven

Amy L. Fletcher, University of Canterbury

Brigitte Geissel, Technical University of Berlin

Rupert Gordon, University of Toronto

Heike Hagedorn, University of Muenster Lisa Hill, Australian National University Yong-Ki Kim, London School of Economics

Bettina Koch, University of Vechta Miriam Laugesen, University of Melbourne

Mechtild Lauth, Universitat Leipzig William Maloney, University of Aberdeen

Petra Meier, Vrije University

Gagik Melkonyan, Yerevan Institute of Foreign Languages

Peter Meyers, Université de Lille III Abdul Noury, Universite Libre de Bruxelles

Roland Pierik, Tillsburg Univeristy Ingrid Robeyns, Cambridge University Wolfgang Rudig, University of Strathclyde

Uwe Serdult, University of Pittsburgh Ben Seyd, University College of London Abdollah Payrow Shabani, University of Ottowa

Laszlo Vass, Budapest University John von Heyking, University of Lethbridge

Mary Walsh, Queensland University of Technology

Stephen White, University of Glasgow

Maureen Whitebrook, University of

Sheffield

Stefan Wolff, University of Bath

Chung-li Wu, National Chung Cheug

University

Tatyana Zakharova, Academy of Public Service

Chian-Fan Zhang, Nanjing University 


\section{Research Grant Competition}

The APSA Council invites applications to the Small Research Grant Program for research in all fields of political science. The Committee on Education and Professional Development and the Research Support Advisory Board select grantees and oversee the program.

\section{SCOPE OFTHE AWARD}

Projects should address a significant issue in any field of political science. In honor of our upcoming centennial, proposals that emphasize an element of history of the discipline, profession, or Association are especially invited.

\section{FUNDING}

The Council has made $\$ 23,400$ available for the 2001 Small Research Grants. Individual grants will not exceed $\$ 2500$ and are not renewable.

Applicants must be APSA members at the time of application, and may not have received an APSA Research Grant in the prior three years. In addition, the principal investigator must be one of the following: (a) a political science faculty member at a college or university that does not award a Ph.D in political science; or (b) a political scientist not affiliated with an academic institution. This grant does not provide support for dissertation research or writing.

WHAT ARE THE GUIDELINES?

WHAT ARE THE APPLICATION PROCEDURES?

Proposals must (1) specify research design;

(2) state how the project relates to previous research and theoretical developments; and (3) state how the project contributes to scholarship within a field.

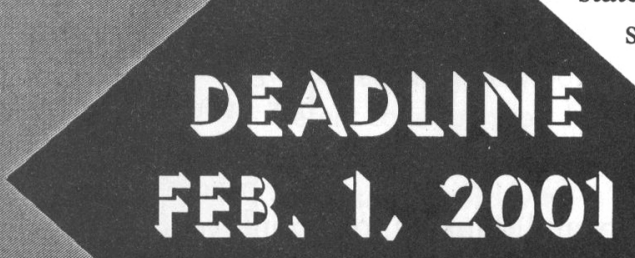

Funds may be used for such research activities as: travel to archives; travel to conduct interviews; administration and coding of survey instruments; and purchase of data sets. This list is merely illustrative, but specifically excluded from funding are: travel to professional meetings; secretarial costs except for preparation of the final manuscripts for publication; institutional overhead and salary support for the principal investigator.

Proposals should be no more than five pages (singlespaced) with a title page listing: name, title of project, current affiliation, and amount requested. Proposals must have a budget justification, and curriculum vitae attached. See our website at http://www.apsanet.org/opps/srg for more detailed information. Inquiries may be directed to grants@apsanet.org.

Six (6) copies each of the proposal budget, and curriculum vitae should be submitted to:
APSA Small Grants Competition

American Political Science Association

1527 New Hampshire Ave NW,

Washington, DC 20036-1206

http://www.apsanet.org 